\title{
REVIEW
}

\section{A review of the "OMICS" for management of patients with obstructive sleep apnoea}

\author{
Una review sulle scienze OMICHE nella gestione del paziente \\ con sindrome dell'apnea ostruttiva del sonno
}

\author{
Luana Conte ${ }^{1,2}$, Marco Greco ${ }^{1,3}$, Domenico Maurizio Toraldo4, Michele Arigliani5 ${ }^{5}$, Michele Maffia ${ }^{1,3,6}$, \\ Michele De Benedetto ${ }^{1}$ \\ ${ }^{1}$ Interdisciplinary Laboratory of Applied Research in Medicine (DReAM), University of Salento, Lecce, Italy; ${ }^{2}$ Laboratory of Advanced \\ Data Analysis for Medicine (ADAM), Department of Mathematics and Physics "E. De Giorgi", University of Salento, Lecce, Italy;; \\ ${ }^{3}$ Laboratory of Physiology, Department of Biological and Environmental Sciences and Technologies, University of Salento, Lecce, Italy; \\ ${ }^{4}$ Department Rehabilitation "V. Fazzi" Hospital, Cardio-Respiratory Unit Care, ASL-Lecce, San Cesario di Lecce (LE), Italy; ${ }^{5}$ V. Fazzi \\ Hospital, ENT Unit, ASL Lecce, Italy; ' ${ }^{\circ}$ Laboratory of Clinical Proteomic, "Giovanni Paolo II" Hospital, ASL-Lecce, Italy
}

\section{SUMMARY}

Obstructive sleep apnaea (OSA) syndrome is a condition characterised by the presence of complete or partial collapse of the upper airways during sleep, resulting in fragmentation of sleep associated with rapid episodes of intermittent hypoxia (IH), activation of the sympathetic nervous system and oxidative stress. OSA is associated with a broad spectrum of cardiovascular, metabolic and neurocognitive comorbidities that appear to be particularly evident in obese patients, while affecting both sexes in a different manner and varying in severity according to gender and age. In recent years, studies on OSA have increased considerably, but in clinical practice, it is still a highly underdiagnosed disease. To date, the gold standard for the diagnosis of OSA is nocturnal polysomnography (PSG). However, since it is not well suited for a large number of patients, the Home Sleep Test (HST) is also an accepted diagnostic method. Currently, the major aim of research is to identify non-invasive methods to achieve a highly predictive, non-invasive screening system for these subjects. The most recent reports indicate that research in this field has made significant progress in identifying possible biomarkers in OSA, using -OMIC approaches, particularly in the fields of proteomics and metabolomics. In this review, we analyse these OMIC biomarkers found in the literature.

KEY WORDS: OMICS, proteomics, metabolomics, OSA

\section{RIASSUNTO}

La sindrome da apnea ostruttiva nel sonno (OSA) è una condizione caratterizzata dalla presenza di completo o parziale collasso delle vie aeree superiori durante il sonno, con conseguente frammentazione del sonno associata a rapidi episodi di ipossia intermittente (IH) e attivazione del sistema nervoso simpatico e dello stress ossidativo. L'OSA è associata ad un ampio spettro di patologie cardiovascolari, metaboliche, neurocognitive e comorbidità che appaiono particolarmente evidenti nei pazienti obesi, interessando entrambi i sessi in modo diverso e variando la gravità a seconda del sesso e dell'età. Negli ultimi anni, gli studi sull'OSA sono aumentati considerevolmente, ma nella pratica clinica, si tratta ancora di una malattia altamente sottodiagnosticata. Ad oggi, il gold standard per la diagnosi di OSA è la polisonnografia notturna (PSG). Tuttavia, poiché non è adatto ad un gran numero di pazienti, anche l'Home Sleep Test (HST) è un metodo diagnostico accettato. Attualmente, l'obiettivo principale della ricerca è quello di identificare metodi non invasivi per ottenere un sistema di screening altamente predittivo e non invasivo per questa categoria di soggetti. I lavori più recenti indicano che la ricerca in questo campo ha compiuto progressi significativi nell'identificazione di possibili biomarcatori in OSA, utilizzando approcci OMICI, in particolare nel campo della proteomica e della metabolomica. In questa review, analizziamo una lista di questi biomarcatori presenti in letteratura.

PAROLE CHIAVE: OSA, scienze omiche, proteomica, metabolomica
Received: July 30, 2019

Accepted: September 21, 2019

\section{Correspondence}

Luana Conte

Palazzina Direzione Amministrativa, I Piano DREAM, Presidio Ospedaliero "V.Fazzi", piazza

F. Muratore 1, 73100 Lecce, Italy

Tel. +390832 335022

E-mail: luana.conte@unisalento.it

Funding

None.

Conflict of interest

The Authors declare no conflict of interest.

How to cite this article: Conte L, Greco M, Toraldo DM, et al. A review of the "OMICS" for management of patients with obstructive sleep apnoea. Acta Otorhinolaryngol Ital 2020;40:164172. https://doi.org/10.14639/0392-100X-N0409

C Società Italiana di Otorinolaringoiatria e Chirurgia Cervico-Facciale

\section{(c) (i) $\odot$}

This is an open access article distributed in accordance with the CC-BY-NC-ND (Creative Commons Attribution-NonCommercial-NoDerivatives 4.0 International) license. The article can be used by giving appropriate credit and mentioning the license, but only for non-commercial purposes and only in the original version. For further information: https:// creativecommons.org/licenses/by-nc-nd/4.0/deed.en 


\section{Introduction}

Obstructive sleep apnoea (OSA) is considered by far the most important form of sleep disturbance in breathing. It is caused by increased collapsibility or insufficiency/loss of muscular dilation capacity of the upper airways, leading to repeated pharyngeal constriction (hypopnoea) or closure (apnoea), therefore resulting in decreasing oxyhaemoglobin saturation and with increasing partial pressure of carbon dioxide in arterial blood ' . To restore pharyngeal patency, patients experience recurrent awakenings, resulting in fragmented sleep, followed by reduced cognitive performance and, in some cases, diurnal sleepiness episodes.

Despite its high prevalence and the high burden of morbidity, OSA remains a significantly underdiagnosed disease worldwide. The Hypnolaus study estimated that the prevalence of moderate-to-severe sleep-disordered breathing ( $\geq 15$ events per $\mathrm{h}$ ) was $23.4 \%$ (95\% confidence interval (CI), with a range of 20.9-26.0) in women and $49.7 \%$ (with a range of 46.6-52.8) in men ${ }^{2}$, whereas according to the American Academy of Sleep Medicine ${ }^{3}$, only $20 \%$ of patients are diagnosed (about 6 million of a total of 24 million) in the US. The annual cost for an undiagnosed patient is estimated at around $\$ 5,500$ (considering direct and indirect health costs), while it decreases to $\$ 2,100$ per year for diagnosed patients ${ }^{4}$. On this basis, it is evident that OSA is not only a serious health problem, but also a socio-economic issue.

OSA is also becoming dangerously frequent in children, associated with adenotonsillar hypertrophy ${ }^{5}$ as well as high rates of overweight and obesity in children in Western countries. These trends will have disastrous long-term consequences for global health and life expectancy if solutions are not taken to correct erroneous lifestyles from the earliest age ${ }^{6}$. These data also suggest that the only way to make the costs of OSA sustainable is through prevention. To date, the gold standard for diagnosis of OSA is nocturnal polysomnography (PSG). This sleep examination utilises electroencephalography, electrooculography in both eyes, sub-mental electromyography, nasal airflow, snoring sounds, electrocardiography, thoracic/abdominal movements, pulse oxygen saturation and body position to measure various parameters. The PSG indices included are apnoea-hypopnoea index (AHI) and oxygen desaturation index. However, since it is not well suited for a large number of patients, the Home Sleep Test (HST) is also an accepted diagnostic method ${ }^{7,8}$. Given the difficulty of applying the HST to the population as a screening system due to high costs and examination timing, researchers are currently focusing on identifying new biomarkers for early diagnosis of OSA ${ }^{9}$. In the case of sleep disorders and lung diseases, traditional biomarker research techniques have proved to be not particularly well performing.
Studies based on proteomics and metabolomics, however, are more sensitive, although, to date, the number of molecules potentially available for clinical application in the context of OSA is still limited. The development of new technologies is therefore necessary, also to provide a greater understanding of the biochemical mechanisms involved in OSA.

In Table I, the list of proteins and metabolites differently expressed in OSA subjects identified in the literature is reported.

\section{Proteomics approaches}

The study of the proteome in OSA patients has been broadly assessed. Many studies have reported that OSA patients express increased levels of mediators of systemic inflammatory response. Zhang et al. ${ }^{10}$ used, for the first time, a proteomic approach to detect protein profiles of serum extracellular microvescicle proteins in an intermittent hypoxia (IH) rodent model ${ }^{11}$. Extracellular microvescicles are vesicles released from cells into the extracellular fluid environment, including serum. Their potential utility in clinical diagnosis is well documented, since vesicles are reported to reflect the physiological or pathological status of the tissue from which they arise. They found 4 differentially expressed proteins in serum extracellular microvesicles compared to control: C-reactive protein (CRP), haptoglobin (HP), fibronectin (FN1) and platelet factor 4 (PF4). In addition, Nadeem et al., through meta-analysis of the literature ${ }^{12}$, confirmed altered levels of CRP and other systemic inflammatory mediators, including intercellular adhesion molecules (ICAM), coagulation factors (factor VIII, tissue factor) and a significant increase in serum levels of tumour necrosis factor alpha (TNF- $\alpha$ ), interleukin $1 \beta$ (IL-1 $\beta$ ) and interleukin 6 (IL-6) in patients with OSA. The excessive infiltration of inflammatory cells is also highlighted by the formation of subepithelial oedema in OSA patients as documented by histology. Among these proteins, circulating CRP is an important predictive factor of cardiovascular risk involved in the onset and progression of atherosclerosis ${ }^{13,14}$. Its pro-inflammatory and atherogenic properties have been found in endothelial cells, both smooth and striated muscle cells and macrophages. Its levels, as well as those of IL-6, are strongly associated with oxidative stress or anoxia ${ }^{10,15}$ A similarly important role in the clinical picture of the OSA patient is the high level of TNF- $\alpha$ observed; it is, in fact, a pro-inflammatory cytokine with an important role in the host defence, which at the same time mediates the onset of a series of pathological processes including atherosclerosis, septic shock and autoimmune diseases. The release of TNF- $\alpha$ is mediated by IL-6, as well as by other pro-inflammatory cytokines such as IL-2, IFN- $\gamma$ and by TNF- $\alpha$ itself through a positive feedback process ${ }^{16}$. 
Table I. Metabolites and proteins found in OSA patients through OMICS approaches.

\begin{tabular}{|c|c|c|c|c|}
\hline Reference & Sample & $\begin{array}{c}\text { Number } \\
\text { of participants }\end{array}$ & $\begin{array}{l}\text { Proteins/ } \\
\text { metabolites }\end{array}$ & $\begin{array}{l}\text { Differently expressed } \\
\text { biomarkers }\end{array}$ \\
\hline $\begin{array}{l}\text { Chen et al. } \\
2017^{69}\end{array}$ & $\begin{array}{l}\text { Peripheral } \\
\text { blood } \\
\text { mononuclear } \\
\text { cells }\end{array}$ & $\begin{array}{l}48 \text { patients } \\
\text { with sleep-disordered } \\
\text { breathing }\end{array}$ & Proteins & $\begin{array}{c}\text { Angiomotin (AMOT), pleckstrin homology, MyTH4 and FERM domain containing } \\
\text { H3 (PLEKHH3), adenosine deaminase RNA specific (ADAR), baculoviral IAP } \\
\text { repeat containing } 3 \text { (BIRC3), and galectin } 3 \text { (LGALS3) proteins }\end{array}$ \\
\hline $\begin{array}{l}\text { Krishna et al. } \\
2006^{64}\end{array}$ & Urine & $\begin{array}{c}11 \text { paediatrics OSA and } \\
11 \text { controls }\end{array}$ & Proteins & Gelsolin, Perlecan (a heparan sulfate proteoglycan), Albumin, Immunoglobulin \\
\hline $\begin{array}{l}\text { Shah et al. } \\
2006^{65}\end{array}$ & Serum & $\begin{array}{l}20 \text { paediatrics OSA and } \\
20 \text { controls }\end{array}$ & Proteins & 3 proteins with molecular masses of 5896, 3306 and $6068 \mathrm{Da}$ \\
\hline $\begin{array}{l}\text { Gozal et al. } \\
200966\end{array}$ & Urine & $\begin{array}{l}30 \text { paediatrics OSA and } \\
30 \text { controls }\end{array}$ & Proteins & $\begin{array}{c}\text { Uromodulin, Urocortin-3, Kallikrein, Bikunin, Tenascin, Human Tribbles } \\
\text { homolog-2, Zinc finger protein-81, 36/1, Orosomucoid-2, a1-Microglobulin, } \\
\text { PCAF histone acetylase, Prolyl hydroxylase domain }\end{array}$ \\
\hline $\begin{array}{l}\text { Becker et al. } \\
2014{ }^{70}\end{array}$ & Urine & $\begin{array}{c}14 \text { paediatrics OSA and } \\
13 \text { controls }\end{array}$ & Proteins & 30-fold more candidate biomarkers \\
\hline $\begin{array}{l}\text { Jurado-Gamez } \\
\text { et al. } 2012^{33}\end{array}$ & Serum & $\begin{array}{l}30 \text { OSA } \\
\text { and } 10 \text { controls }\end{array}$ & Proteins & 30 proteins \\
\hline $\begin{array}{l}\text { Seetho et al. } \\
2014^{67}\end{array}$ & Urine & 27 OSA and 25 controls & Proteins & 15 peptides \\
\hline $\begin{array}{l}\text { Zheng et al. } \\
2014^{30}\end{array}$ & Saliva & $\begin{array}{l}20 \text { Non-CVD OSA } \\
\text { and } 18 \text { CVD OSA }\end{array}$ & Proteins & $\begin{array}{c}\text { Fibrinogen alpha chain (FGA), Alpha-2-HS-glycoprotein (AHSG), Tubulin alpha- } \\
4 A \text { chain (TUBA4A) and other } 7 \text { differentially expressed peptides still } \\
\text { to be identified }\end{array}$ \\
\hline $\begin{array}{l}\text { Ferrarini et al. } \\
2013^{34}\end{array}$ & Plasma & $\begin{array}{l}18 \text { OSA severe } \\
\text { and } 15 \text { OSA } \\
\text { non severe }\end{array}$ & Metabolites & $\begin{array}{c}\text { Phosphatidylcholine (PC), Phosphoserine (PS), } \\
\text { Lysophosphatilysophosphatidylcholines (LPC), Lysophosphatidylethanolamine } \\
\text { (LPE), LPA, PE methyl-hydroperoxy-octadecatrienoate, PGF2-alpha diethyl amide } \\
\text { Pipecolic acid, Arg, Phe, His }\end{array}$ \\
\hline $\begin{array}{l}\text { Kawai et al. } \\
2013^{3}\end{array}$ & Saliva & 20 male OSA & Metabolites & Phosphatidylcholine (PC) \\
\hline $\begin{array}{l}\text { Engeli et al. } \\
2012^{37}\end{array}$ & Plasma & $\begin{array}{l}29 \text { OSA, } \\
26 \text { OSA type II diabetes, } \\
21 \text { controls }\end{array}$ & Metabolites & $\begin{array}{l}\text { Anandamide; (AEA), Arachidonoylglycerols; (AG), Oleoyl ethanolamide; (OEA), } \\
\text { Arachidonic acid (AA), increase in the total monounsaturated fatty acids (MUFA) }\end{array}$ \\
\hline $\begin{array}{l}\text { Ezzedini et al. } \\
2013^{39}\end{array}$ & Tonsillar tissue & $\begin{array}{l}114 \text { pediatrics } 0 \text { SA } \\
\text { and } 92 \text { recurrent tonsillitis }\end{array}$ & Metabolites & Palmitoleic acid, Oleic acid, Stearic acid \\
\hline $\begin{array}{l}\text { Papandreu et } \\
\text { al. } 2013^{38}\end{array}$ & Adipose tissue & 63 OSA & Metabolites & $\begin{array}{l}\text { Myristic, Palmitic, Stearic, Oleic acid, n-6 fatty acids n-3 (precursors of } \\
\text { prostaglandins and serotonin) and n-6 fatty acids }\end{array}$ \\
\hline $\begin{array}{l}\text { Fletcher et al. } \\
1987^{60}\end{array}$ & Urine & $\begin{array}{l}8 \text { severe OSA } \\
\text { and } 5 \text { HTN and obese } \\
\text { non OSA patients }\end{array}$ & Metabolites & $\begin{array}{c}\text { Epinephrine (E), Norepinephrine (NE), Metanephrine (MN), } \\
\text { Normetanephrine (NMN) }\end{array}$ \\
\hline $\begin{array}{l}\text { Paci et al. } \\
200045\end{array}$ & Plasma & $\begin{array}{l}10 \text { male OSA } \\
\text { (8 normotensive and } 2 \\
\text { untreated HTN) } \\
\text { and } 11 \text { controls }\end{array}$ & Metabolites & $\begin{array}{c}\text { Norepinephrine (NE), Epinephrine (E), Dopamine (DA), } \\
\text { Endogenous digitalis-like factor (EDLF) }\end{array}$ \\
\hline $\begin{array}{l}\text { O’Driscoll et al. } \\
2011^{62}\end{array}$ & Urine & $\begin{array}{l}70 \text { snorers and } 26 \\
\text { controls }\end{array}$ & Metabolites & Epinephrine (E), Norepinephrine (NE), Dopamine (DA), Noradrenaline, Adrenaline \\
\hline $\begin{array}{l}\text { Paik et al. } \\
2014{ }^{61}\end{array}$ & Urine & $\begin{array}{l}49 \text { OSA (of which } \\
23 \text { with insomnia) }\end{array}$ & Metabolites & Homovanillic acid (HVA), 3,4-dihydroxyphenylacetic acid (DOPAC) \\
\hline $\begin{array}{l}\text { Gislason et al. } \\
199263\end{array}$ & $\begin{array}{l}\text { Cerebrospinal } \\
\quad \text { fluid }\end{array}$ & $\begin{array}{l}15 \text { OSA and } 18 \\
\text { healthy controls, } 12 \\
\text { patients with suspected } \\
\text { neurological disease }\end{array}$ & Metabolites & $\begin{array}{l}\text { 5-hydroxyindoleacetic acid (5-HIAA, serotonin } \\
\text { metabolite), Homovanillic acid (HVA, DA } \\
\text { metabolite), 3-methoxy-4-hydroxyphenyl glycol (MHPG) }\end{array}$ \\
\hline $\begin{array}{l}\text { Dikmenoglu et } \\
\text { al. } 2006^{47}\end{array}$ & Plasma & 11 OSA and 11 controls & $\begin{array}{l}\text { Metabolites/ } \\
\text { proteins }\end{array}$ & Malondialdehyde (MDA), fibrinogen \\
\hline $\begin{array}{l}\text { Stanke- } \\
\text { Labesque } \\
\text { et al. } 2009^{51}\end{array}$ & Urine & $\begin{array}{c}40 \text { non obese OSA and } \\
20 \text { controls }\end{array}$ & Metabolites & Leukotriene E(4) (U-LTE (4)), 11-dehydroTXB2 \\
\hline
\end{tabular}


Table I. Follows.

\begin{tabular}{|c|c|c|c|c|}
\hline $\begin{array}{l}\text { Barcelò et al. } \\
2012^{31}\end{array}$ & Saliva & $\begin{array}{l}119 \text { OSAS and } 35 \\
\text { controls }\end{array}$ & Metabolites & Gamma glutamyltransferase (GGT), Fetuin-A, \\
\hline $\begin{array}{l}\text { Zhang et al. } \\
2018^{10}\end{array}$ & $\begin{array}{c}\text { Serum } \\
\text { extracellular } \\
\text { microvescicles }\end{array}$ & 20 OSA and 20 controls & Proteins & $\begin{array}{c}\text { Haptoglobin, C-reactive protein (CRP), Platelet factor } 4 \text { (PF4), Coagulation factor } \\
\text { XIII (F13a1), Fibronectin (FN1) }\end{array}$ \\
\hline $\begin{array}{l}\text { Lebkuchen et } \\
\text { al. } 2018^{35}\end{array}$ & Plasma & 37 OSA and 16 controls & Metabolites & $\begin{array}{c}\text { Deoxy sugar; 2,6-diphenyl-1,7-dihydrodipyrrolo[2,3-b:3',2'-e] pyridine; } \\
\text { 9-hexadecenoic acid (Z), Arachidonic acid (AA), 5,5'-biphthalide, L-glutamine, } \\
\text { Glycerophosphoethanolamines (PE), Monoacylglycerophosphocholines (lyso- } \\
\text { phosphocholines) (LPC), sphingomyelin (SM), diacylglycerols (DAG), } \\
\text { glycerophosphocholines (PC), glycerophosphates (PA), Glutamic acid, } \\
\text { Methyl cysteine, Serine }\end{array}$ \\
\hline $\begin{array}{l}\text { Xu et al. } \\
2016^{50}\end{array}$ & $\begin{array}{l}\text { Urine } \\
\text { and plasma }\end{array}$ & $\begin{array}{l}60 \text { OSA, } 30 \text { simple } \\
\text { snorers and } 30 \text { controls }\end{array}$ & Metabolites & $\begin{array}{l}\text { 2-hydroxy-3-methylbutyric acid, 3,4-dihydrxoybutyric acid, 3-hydroxybutyric } \\
\text { acid, 4-hydroxypentenoic acid, cytidine 5'-diphosphocholine, ethanolamine, } \\
\text { myo-inositol, 2,3-dihydrxoypropanoic acid, arabinose, arabitol, cellobiose, } \\
\text { maltose, threitol, alanine, isoleucine, serine, threoninyl-methionine, } \\
\text { trimethylamine N-oxide, valine, 5-hydroxyindoleacetic acid, lactic acid, } \\
\text { glycochenodeoxycholate-3-sulfate, putrescine, 4-hydroxybutyric acid, vanillic } \\
\text { acid, hypoxanthine, inosine, xanthine }\end{array}$ \\
\hline
\end{tabular}

An analysis of whole-genomic microarrays recently carried out by Yung-Che et al. found overexpression of angiomotin (AMOT), pleckstrin homology, MyTH4 and FERM domain containing H3 (PLEKHH3), adenosine deaminase RNA specific (ADAR), baculoviral IAP repeat containing 3 (BIRC3) and galectin 3 (LGALS3) proteins in treatmentnaïve OSA patients ${ }^{17}$. LGALS3 has shown to be involved in cancer, inflammation and fibrosis, heart disease and stroke. Studies have also suggested that expression of galectin-3 is implicated in a variety of processes associated with heart failure, including myofibroblast proliferation, fibrogenesis, tissue repair, inflammation and ventricular remodelling ${ }^{18}$.

Expression of AMOT in endothelial cells and its level is associated with proliferation and invasion of breast tumours ${ }^{19}$. ADAR are double chain RNA editing enzymes responsible for post-transcriptional modification of mRNA transcripts by changing the nucleotide content of the RNA. The conversion from A to I in the RNA disrupts the normal A:U pairing which makes the RNA unstable ${ }^{20}$. ADAR is considered to be involved in the insurgence of cancer. Studies in the sleep field also revealed that the ADA G22A polymorphism (c. $22 \mathrm{G}>\mathrm{A}$, rs73598374) is associated with fewer awakenings throughout the night, and a higher duration of slow wave sleep (SWS), as compared to the normal ADA G22G genotype ${ }^{21}$.

BIRC3 is a downstream effector of the ubiquitous hypoxiainducible factor (HIF-1 $\alpha$ ) that is involved in pro-survival and inflammatory responses induced by the docosahexaenoic acid/neuroprotectin D1 pathway under oxidative stress in an ischaemia-reperfusion stroke model. HIF- $1 \alpha$ functions as a principle regulator activity of cellular and systemic homeostatic response to hypoxia. This heterodimer is composed of an alpha and a beta subunit that can activate the transcription of many genes, including those involved in energy metabolism, apoptosis and angiogenesis, as well as other genes whose protein products increase oxygen delivery and facilitate metabolic adaptation to hypoxia. Since many studies have shown that OSA is associated with an imbalance between oxidant production and antioxidant activity, this fact, combined with an overabundance of oxidants, can be linked to the multifactorial aetiology of metabolic disorders, including insulin resistance ${ }^{22}$.

Almendros et al. ${ }^{23}$ examined the correlation between HIF$1 \alpha$ factor and vascular endothelial growth factor (VEGF) expression in patients with cutaneous melanoma. Interestingly, they found in a large prospective study that the expression of HIF-1 $\alpha$ was an independent factor associated with nocturnal $\mathrm{IH}$ measures of respiratory disturbance during sleep in patients affected by cutaneous melanoma ${ }^{23}$, meaning that it has a significant contribution to the disease. Notably, the risk of melanoma was significantly higher in patients with OSA $(\mathrm{HR}=1.14,95 \% \mathrm{CI} 1.10-1.18)$, along with pancreatic and kidney cancer ${ }^{24}$. In recent years, other potential associations between OSA and cancer have been reported, principally ascribed to an effect of IH on tumour biology ${ }^{25-27}$.

A significant correlation between OSA and increased cardiovascular risk and hypertension (HTN) is strongly reported in the literature ${ }^{28,29}$. Mass spectrometry was performed on salivary samples of OSA patients with cardiovascular diseases (CVD) compared to non-CVD OSA patients ${ }^{30}$. A panel of 11 biomarkers were identified as differentially expressed between the two groups. It was found that the level of alpha-2-HSglycoprotein (AHSG) peptide was significantly lower in the OSA-CVD group compared to the non-CVD group. A reduced level of AHSG had already been reported in severe OSA patients ${ }^{31}$ at metabolic level ${ }^{32}$. AHSG protein is synthesised by hepatocytes and is involved in different process such as formation of brain and bone and endocytosis. Interestingly, lack of this protein is involved in leanness. 


\section{Metabolomics approach}

The field of metabolomics, and the consequent search for potential biomarkers in OSA patients, is beginning to be explored only in recent years. The lipidomic profile in OSA patients reported in the literature mainly reveals alterations in phospholipid biosynthesis and fatty acids. One of the major studies using mass spectrometry has allowed to identify, both at a serum and urinary level, as many as 103 proteins that are differently expressed in adult OSA patients compared to controls, all potentially associated with imbalances in lipid metabolism and alterations in the vascular system ${ }^{33}$. Among phospholipids, glycerophosphocholines (PC), lysophosphatidylcholines (LPE), glycerophosphoethanolamines (PE), lysophosphatidylethanolamine (LPA), phosphoserine (PS), and lysophosphatidic acids, along with glycerophosphates (PA), monoacylglycerophosphocholines, lyso-phosphocolyne (LPC) and sphingomyelin (SM) classes were found to be up-regulated in patients with OSA compared to controls ${ }^{34,35}$. Increased PC expression at the salivary level was also reported using LC-MS/MS methods ${ }^{36,37}$.

Alterations in fatty acids have also been detected. Among those that are significantly increased in OSA compared to normal subjects, circulating anandamide (AEA), 2,4-dihydroxybutyric acid, 2-hydroxy-3-methylbutyric acid, 3,4-dihydrxoybutyric acid, 6-aminocaproic acid, pentanoic acid, and glyceraldehyde, 3-methyl-3-hydroxybutyric acid, and 4-hydroxypentenoic acid were up-regulated, whereas bile acid and glycochenodeoxycholate-3-sulphate (GCDCA3 -sulphate) were decreased ${ }^{36-38}$. Other groups, using GC-LC techniques, found that palmitoleic and oleic acid levels were lower, while stearic acid levels were higher in the tonsillitis tissue of infant control subjects compared to the hyperplastic tissue typical of the diseased counterpart ${ }^{39}$.

Other research groups observed that in OSA patients levels of 1/2-arachidonoylglycerols (AG), and oleoyl ethanolamide (OEA) in plasma are higher compared to controls. It is interesting to note that arachidonic acid (AA) concentrations and eicosanoids ${ }^{34,35}$ were also up-regulated in OSA patients, suggesting a role for the endocannabinoid system in regulating blood pressure in patients with high risk OSA for HTN and CVD ${ }^{36,37,40}$.

Theendocannabinoid systemis, infact, based on lipidmolecules produced by the body in response to various stimuli that bind specific membrane receptors associated with the protein $\mathrm{G}$, called cannabinoid receptors type 1 and 2 (CB1 and CB2) ${ }^{41}$. The endocannabinoid system represents a neuromodulation system, playing a role in the control of pain at the level of the central nervous system, in regulation of cell proliferation and in modulation of the immune response. Interestingly, it also seems to play a role in mechanisms that modulate appetite and therefore obesity ${ }^{37}$. The endocannabinoid system also plays an important role in the release of adipokines. Recent research has shown that the pharmacological blockade of CB1 by an antagonist, named Rimonabant, stimulates the release of adiponectin, which is normally inhibited. Adiponectin is a circulating hormone secreted by adipose tissue, with antiatherogenic and antidiabetic properties that can reduce liver glucose production, as well as suppress lipogenesis and activate oxidation of fatty acids ${ }^{42}$. How endocannabinoids regulate metabolism are still only partially understood, despite the fact that their role in controlling hunger and satiety acts mainly in hypothalamic structures through activation of neurons capable of stimulating the action of neuropeptides ${ }^{43}$. Alterations in the endocannabinoid system therefore affect and alter energy metabolism of the body and homeostasis of lipids, as suggested by Di Marzo and Matias, who were the first to formulate the increasingly valid hypothesis that obesity can be associated with pathological hyperactivation of the endocannabinoid system ${ }^{44}$. All these conditions can be associated with an increased risk of cardiometabolic diseases such as type 2 diabetes, dyslipidaemia, arterial hypertension, myocardial infarction and stroke, conditions normally found in OSA patients.

Mediators involved in the systemic inflammatory response and oxidative stress have also been reported in OSA. Among the metabolites associated with oxidative stress, urinary 15-F2t- isoprostane, one of the most sensitive metabolites correlated with lipid peroxidation, is positively linked to thickness of the intima-media carotid tunic ${ }^{45}$. These molecules were shown to be a specific, chemically stable, quantitative marker of oxidative stress in vivo. In particular, F2t-isoprostanes are prostaglandin isomers synthesised in vivo through free radical catalysed peroxidation of AA in biological membranes, independently of the activity of cyclo-oxygenase. Increased urinary excretion or plasma concentrations of 15-F2t-isoprostane has been observed in many conditions including smoking, diabetes and cardiovascular diseases ${ }^{46}$.

Another important biomarker of oxidative stress, malondialdehyde (MDA), is present at significantly higher concentrations in patients with OSA vs. control ${ }^{47}$. MDA is the result of lipid peroxidation of polyunsaturated fatty acids. It is an important product in the synthesis of thromboxane A2 in which cyclooxygenase 1 or cyclooxygenase 2 metabolises AA into prostaglandin $\mathrm{H} 2$ and ROS degrade polyunsaturated lipids to form MDA ${ }^{48}$. This compound is a reactive aldehyde and is one of many reactive electrophilic species that causes toxic stress in cells and reacts with deoxyadenosine and deoxyguanosine in DNA, forming DNA adducts; it can thus be used as a biomarker to measure the level of oxidative stress in an organism ${ }^{49}$. 
Arguably, the tricarboxylic acid cycle (TCA) and its mediators tend to increase in OSA ${ }^{50}$, suggesting augmentation of oxidative stress.

Among metabolites that are potential pro-inflammatory markers, Stanke-Labesque et al. ${ }^{51}$ found leucotriene E4 (U-LTE4), an inflammatory molecule associated with cysteinyl leukotriene production, whose elevation in urinary concentration has been demonstrated in patients with OSA. Recently, Gautier-Veyret and his group have shown that activation of this pathway contributes to OSA-induced atherogenesis, and its blockade could therefore represent a new therapeutic target for reducing CVD ${ }^{52}$. It is also interesting to note that Continuous Positive Airway Pressure (CPAP), a respiratory ventilation method mainly used in the treatment of sleep apnoea, reduces the urinary concentration of U-LTE4 by up to $22 \%$, but only if the treatment is carried out in patients with a normal body mass index (BMI) ${ }^{51}$.

Arguably, CPAP treatment reduces also serum levels of homocysteine (Hcy) by almost 30\%, which, along with plasma levels, were found to be significantly higher in patients with OSA compared to controls ${ }^{38,39,53}$. In addition, neural-like cell exposure to Hcy for a period of 5 days resulted in a 4.4-fold increase in production of reactive oxidative species (ROS) ${ }^{54}$. Hcy is known to mediate adverse effects on the cardiovascular endothelium and smooth muscle cells with resultant alterations in subclinical arterial structure and function ${ }^{55}$, leading to CVD and its complications, such as heart attack and stroke ${ }^{56}$. Moreover, hyperhomocysteinaemia leads to enhancement of the adverse effects of risk factors like HTN, smoking, and lipid and lipoprotein metabolism, as well as promotion of inflammation ${ }^{57}$. Another study demonstrated that Hcy is capable of initiating an inflammatory response in vascular smooth muscle cells by stimulating CRP production, which is mediated through the NMDAr-ROS-ERK1/2/p38-NF- $\mathrm{BB}$ signal pathway ${ }^{58}$. CRP expression was also found to be altered in the proteome of OSA patients (see previous section).

Some studies also suggest that elevated Hcy levels may be associated with alterations in mental health such as cognitive impairment, dementia, depression, Alzheimer's and Parkinson's disease ${ }^{59}$ through its capacity to act as a neurotransmitter. In particular, Hcy may act either as a partial agonist at glutamate receptors or as a partial antagonist of the glycine co-agonist site of the NMDA receptor. As such, in the presence of normal glycine levels and normal physiological conditions, Hcy does not cause toxicity but in case of head trauma or stroke, there is an elevation in glycine levels in which instance the neurotoxic effect of Hcy as an agonist outweighs its neuroprotective antagonist effect. This neuronal damage following a stroke has been attributed to the over stimulation of excitatory amino acids such as glutamate and aspartate through activation of NMDA receptors ${ }^{55}$. Ganguly et al. ${ }^{55}$ have investigated how Hcy is able to selectively stimulate the release of these excitatory amino acids in stroke and concluded that they may trigger the release of catecholamine, resulting into detrimental effects in the brain and cardiovascular system. Interestingly, in OSA patients, glutamate metabolites were also found to be significantly altered ${ }^{50}$.

The study of catecholamine metabolites and derivatives as potential predictors of the onset of the pathological process seems particularly promising. Fletcher et al. ${ }^{60}$, for example, observed that norepinephrine (NE) and normetanephrine levels were significantly higher in the urine of patients with OSA than those in obese HTN controls, as well as epinephrine (E) levels, at the plasma level ${ }^{45}$, who also found higher levels of dopamine (DA) in the comparison of 10 male patients with OSA and 11 controls. HPLC observations revealed a significant increase in all urinary catecholamines in OSA children, and the levels of NE and E during the night were strongly related to the severity with which patients manifest the altered phenotype. Paik et al. ${ }^{61}$, after studies carried out using GC-MS to detect metabolites of urinary neurotransmitters, demonstrated that homovanillic acid (HVA) and 3,4-dihydroxyphenylacetic acid (DOPAC), both dopamine metabolites, were increased in sleepy patients with OSA, suggesting that excessive daytime sleepiness in these subjects is probably caused by an increase in night-time activity of the dopaminergic and sympathetic systems ${ }^{62}$. Although this theory seems intriguing, the results of several other studies question it. Paci et al. have reported that $\mathrm{E}$ and DA levels did not vary significantly between OSA patients and controls. In addition, the results of the studies of Gislason et al, found 5-hydroxyindo-lacetic acid (5-HIAA), HVA and 3-methoxy-4-hydroxyphe-glicolenyl glycol (MHPG) in the cerebrospinal fluid of 15 patients with OSA and 18 controls; however, even in this case, the levels of all these biomarkers were similar in patients with OSA and control subjects ${ }^{45,63}$. The inconsistency of the results obtained from the studies on catecholamine metabolites in patients with OSA may be due to various factors such as the heterogeneity of the analytical platforms used by the various research groups, the different biological matrices taken into account, small size of the cohorts and the different protocols used for sample collection. All these elements may also affect the reproducibility of studies.

The first studies aimed at finding differentially expressed metabolites at the urinary level in children with OSA was carried out by Krishna et al. ${ }^{64}$. They adopted a mass spectrometry technique on a cohort of 22 subjects, who demonstrated an alteration in glomerular and tubular filtration of the kidneys compared to healthy counterparts. High levels 
of proteins such as jasmine, perlecan (a heparan sulphate proteoglycan), albumin, and immunoglobulin were detected in urine. These results suggested increased catabolic activity of some proteins in OSA patients ${ }^{64}$. In the same period, Shah et al. also identified three proteins of 5,896, 3,306 and $6,068 \mathrm{kDa}$ that were differently expressed in pathological children, which were capable of discriminating the latter from healthy patients with $90 \%$ specificity and $93 \%$ sensitivity ${ }^{65}$. Three years later, Gozal et al., using a method based on the use of 2-Dimensional DIfference Gel Electrophoresis and Mass Spectrometry (2D-DIGE-MS), were able to identify 16 metabolites differently expressed in the urine of OSA patients compared to controls. In particular, the analysis of concentrations of some of these, including uromodulin, urocortin-3, orosomucoid-1, and kallikrein, were able to identify the pathogenic phenotype with a sensitivity of $95 \%$ and a specificity of $100 \%{ }^{66}$.

The contribution of Seetho et al. and Zeng et al. in the field of research into potential OSA biomarkers is extremely interesting, with the former, focusing on polypeptides using urine of obese OSA patients as a biological matrix, and the second, looking for proteins differently expressed between OSA patients suffering from CVD in saliva. The work of the two groups allowed identification of 27 potential biomarkers, fibrinogen alpha chain (FGA), tubulin alpha-4A chain (TUBA4A) and AHSG. More specifically, AHSG has been shown to be expressed at lower levels in OSA frameworks associated with changes in cardiovascular function ${ }^{30,67}$.

Alterations in amino acid biosynthesis were also reported in OSA using a metabolomics approach. Xu et al. identified 21 differentially expressed urinary metabolites among a simple snoring group and controls, including aspartyl-serine, isoleucine-threonine (Ile-Thr), and methionine, whereas levels of 3-hydroxyanthranilic acid and 5-hydroxytryptophan decreased. Hydroxyprolyl-methionine, hypoxanthine, Ile-Thr, indole-3-acetamide, isoleucine, lactic acid, myoinositol, pentanoic acid, threitol, threoninyl-methionine, trimethylamine $\mathrm{N}$-oxide (TMAO), uridine, and valine were consistently higher or lower ${ }^{50}$. Other groups have also reported that methylcysteine and serine decreased in OSA ${ }^{36,37}$.

The metabolomics profiling of spermine biosynthesis, indoles and tryptophan metabolism, tyrosine metabolism as well as porphyrin metabolism were also altered significantly ${ }^{38,50}$.

\section{Conclusions}

OSA is characterised by recurrent episodes of collapse of the upper airways during sleep, which are reflected in a desaturation of haemoglobin that leads to the awakening of affected subjects. The chronic IH registered in this condition leads the body to enact molecular adaptations to the low- oxygen conditions to which it is subjected ${ }^{68}$. Despite this, sleep fragmentation results in a dangerous condition of excessive sleepiness during the rest of the day. In addition to the long-term problems mentioned, sleep fragmentation is a daily danger for the individual linked to the increased risk of road or work accidents. The body responds to chronic fatigue through compensatory mechanisms that evoke inflammatory responses, hyperactivation of the sympathetic system and alteration of endothelial function, such as regulation of tight junctions; these events have an important role in promoting the onset of atherosclerosis and, in the long term, cardiovascular and cerebrovascular diseases ${ }^{12}$. Recent studies also show a significant correlation between OSA and metabolic and neurocognitive risk as well as an association with cancer mortality.

In the literature, proteomics and metabolomics approaches were used to detect change in physiological or pathological status of OSA patients compared to controls, in order to discover new mediators that can be used as biomarkers of the disease. Notwithstanding, OSA and therapies related to this disease ${ }^{71-73}$, are a somewhat 'new', and there are many proteins and metabolites that are associated with the disease, in particular those involved in inflammation and oxidative stress, in line with the clinical $\mathrm{IH}$ that patients undergo in OSA.

Lipid dysmetabolism in OSA reflects alterations in phospholipids biosynthesis, steroidogenesis and fatty acids. This may influence cell membrane formation, augmenting lipid uptake, atherogenesis and inflammation. In addition, alterations in amino acids, nucleic acids and some mediators that act as neurotransmitters, such as Hcy and the endocannabinoid system, have been seen in OSA patients, suggesting an increased risk of cardiometabolic diseases such as type 2 diabetes, dyslipidaemia, arterial HTN, myocardial infarction and stroke, conditions normally found in OSA patients.

\section{References}

Jordan AS, McSharry DG, Malhotra A. Adult obstructive sleep apnoea. Lancet 2014;383:736-47. https://doi.org/10.1016/S01406736(13)60734-5

2 Heinzer R, Vat S, Marques-Vidal P, et al. Prevalence of sleep-disordered breathing in the general population: the HypnoLaus study. Lancet Respir Med 2015;3:310-8. https://doi.org/10.1016/S22132600(15)00043-0

3 Toraldo DM, Passali D, Sanna A, et al. Cost-effectiveness strategies in OSAS management: a short review. Acta Otorhinolaryngol Ital 2017;37:447-53. https://doi.org/10.14639/0392-100X-1520

4 Pietzsch JB, Garner A, Cipriano LE, et al. An integrated health-economic analysis of diagnostic and therapeutic strategies in the treatment of moderate-to-severe obstructive sleep apnea. Sleep 2011;34:695709. https://doi.org/10.5665/SLEEP.1030

5 Tan H-L, Kheirandish-Gozal L, Gozal D. Adenotonsillectomy in pedi- 
atric OSA: time to look elsewhere. Curr Sleep Med Rep 2018;4:24353. https://doi.org/10.1007/s40675-018-0122-7

6 Hakim F, Kheirandish-Gozal L, Gozal D. Obesity and altered sleep: a pathway to metabolic derangements in children? Semin Pediatr Neurol 2015;22:77-85. https://doi.org/10.1016/j.spen.2015.04.006

7 Facco F, Patel S, Wolsk J, et al. Can we use home sleep testing with autoscore to triage for sleep apnea in obese pregnant women? Am J Obstet Gynecol 2018;218:S491. https://doi.org/10.1016/j. ajog.2017.11.358

8 Orr JE, Sands SA, Edwards BA, et al. Measuring loop gain via home sleep testing in patients with obstructive sleep apnea. Am J Respir Crit Care Med 2018;197:1353-5. https://doi.org/10.1164/rccm.2017071357LE

9 Mullington JM, Abbott SM, Carroll JE, et al. Developing biomarker arrays predicting sleep and circadian-coupled risks to health. Sleep 2016;39:727-36. https://doi.org/10.5665/sleep.5616

10 Zhang H, Yang F, Guo Y, et al. The contribution of chronic intermittent hypoxia to OSAHS: from the perspective of serum extracellular microvesicle proteins. Metabolism 2018;85:97-108. https://doi. org/10.1016/j.metabol.2018.02.012

11 Abuyassin B, Badran M, Ayas NT, et al. Intermittent hypoxia causes histological kidney damage and increases growth factor expression in a mouse model of obstructive sleep apnea. PLoS One 2018;13:e0192084. https://doi.org/10.1371/journal.pone.0192084

12 Nadeem R, Molnar J, Madbouly EM, et al. Serum inflammatory markers in obstructive sleep apnea: a meta-analysis. J Clin Sleep Med 2013;9:1003-12. https://doi.org/10.5664/jcsm.3070

13 Van der Touw T, Andronicos NM, Smart N. Is C-reactive protein elevated in obstructive sleep apnea? A systematic review and metaanalysis. Biomarkers 2019;24:429-35. https://doi.org/10.1080/13547 50X.2019.1600025

14 Ayas NT, Hirsch Allen AJ, Fox N, et al. C-Reactive protein levels and the risk of incident cardiovascular and cerebrovascular events in patients with obstructive sleep apnea. Lung 2019;197:459-64. https:// doi.org/10.1007/s00408-019-00237-0

15 Fleming WE, Holty J-EC, Bogan RK, et al. Use of blood biomarkers to screen for obstructive sleep apnea. Nat Sci Sleep 2018;10:159-67. https://doi.org/10.2147/NSS.S164488

16 Aihara K, Oga T, Chihara Y, et al. Analysis of systemic and airway inflammation in obstructive sleep apnea. Sleep Breath 2013;17:597604. https://doi.org/10.1007/s11325-012-0726-y

17 Chen YC, Chen K Den, Su MC, et al. Genome-wide gene expression array identifies novel genes related to disease severity and excessive daytime sleepiness in patients with obstructive sleep apnea. PLoS One 2017;12:e0176575. https://doi.org/10.1371/journal.pone.0176575

18 Elola MT, Ferragut F, Méndez-Huergo SP, et al. Galectins: multitask signaling molecules linking fibroblast, endothelial and immune cell programs in the tumor microenvironment. Cell Immunol 2018;333:34-45. https://doi.org/10.1016/J.CELLIMM.2018.03.008

19 Moyon A, Garrigue P, Balasse L, et al. Early prediction of revascularisation by angiomotin-targeting positron emission tomography. Theranostics 2018;8:4985-94. https://doi.org/10.7150/thno.27728

20 Samuel CE. Adenosine deaminases acting on RNA (ADARs) are both antiviral and proviral. Virology 2011;411:180-93. https://doi. org/10.1016/j.virol.2010.12.004

${ }_{21}$ Milrad S, Mansoori N, Maidman A, et al. Adenosine Deaminase (ADA1) G22A Allele and sleep-related movement. J Clin Sleep Med 2014;1:1005.

22 Henriksen EJ, Diamond-Stanic MK, Marchionne EM. Oxidative stress and the etiology of insulin resistance and type 2 diabetes. Free Radic Biol Med 2011;51:993-9. https://doi.org/10.1016/j.freeradbiomed.2010.12.005
23 Almendros I, Martínez-García MÁ, Campos-Rodríguez F, et al. Intermittent hypoxia is associated with high hypoxia inducible factor$1 \alpha$ but not high vascular endothelial growth factor cell expression in tumors of cutaneous melanoma patients. Front Neurol 2018;9:272. https://doi.org/10.3389/fneur.2018.00272

24 Gozal D, Ham SA, Mokhlesi B. Sleep apnea and cancer: analysis of a nationwide population sample. Sleep 2016;39:1493-500. https://doi. org/10.5665/sleep.6004

25 Gozal D, Farré R, Nieto FJ. Obstructive sleep apnea and cancer: epidemiologic links and theoretical biological constructs. Sleep Med Rev 2016;27:43-55. https://doi.org/10.1016/J.SMRV.2015.05.006

26 Martínez-García MÁ, Campos-Rodriguez F, Barbé F. Cancer and OSA: current evidence from human studies. Chest 2016;150:451-63. https://doi.org/10.1016/J.CHEST.2016.04.029

27 Hunyor I, Cook KM. Models of intermittent hypoxia and obstructive sleep apnea: molecular pathways and their contribution to cancer. Am J Physiol Regul Integr Comp Physiol 2018;315:R669-87. https:// doi.org/10.1152/ajpregu.00036.2018

28 Drager LF, Genta PR, Pedrosa RP, et al. Characteristics and predictors of obstructive sleep apnea in patients with systemic hypertension. Am J Cardiol 2010;105:1135-9. https://doi.org/10.1016/j.amjcard.2009.12.017

29 Khalyfa A, Kheirandish-Gozal L, Gozal D. Circulating exosomes in obstructive sleep apnea as phenotypic biomarkers and mechanistic messengers of end-organ morbidity. Respir Physiol Neurobiol 2018;256:143-56. https://doi.org/10.1016/J.RESP.2017.06.004

30 Zheng H, Li R, Zhang J, et al. Salivary biomarkers indicate obstructive sleep apnea patients with cardiovascular diseases. Sci Rep 2014;4:7046. https://doi.org/10.1038/srep07046

31 Barceló A, Piérola J, Esquinas C, et al. Reduced plasma fetuin-A levels in patients with obstructive sleep apnoea. Eur Respir J 2012;40:10468. https://doi.org/10.1183/09031936.00011912

32 Dyugovskaya L, Polyakov A, Ginsberg D, et al. Molecular pathways of spontaneous and TNF- $\alpha$ - mediated neutrophil apoptosis under intermittent hypoxia. Am J Respir Cell Mol Biol 2011;45:154-62. https://doi.org/10.1165/rcmb.2010-0025OC

33 Jurado-Gamez B, Gomez-Chaparro JL. Serum proteomic changes in adults with obstructive sleep apnoea. J Sleep Res 2012;21:139-46. https://doi.org/10.1111/j.1365-2869.2011.00955.x

34 Ferrarini A, Rupérez FJ, Erazo M, et al. Fingerprinting-based metabolomic approach with LC-MS to sleep apnea and hypopnea syndrome: A pilot study. Electrophoresis 2013;34:2873-81. https://doi. org/10.1002/elps.201300081

35 Lebkuchen A, Carvalho VM, Venturini G, et al. Metabolomic and lipidomic profile in men with obstructive sleep apnoea: implications for diagnosis and biomarkers of cardiovascular risk. Sci Rep 2018;8:11270. https://doi.org/10.1038/s41598-018-29727-6

36 Kawai M, Kirkness JP, Yamamura S, et al. Increased phosphatidylcholine concentration in saliva reduces surface tension and improves airway patency in obstructive sleep apnoea. J Oral Rehabil 2013;40:75866. https://doi.org/10.1111/joor.12094

37 Engeli S, Blüher M, Jumpertz R, et al. Circulating anandamide and blood pressure in patients with obstructive sleep apnea. J Hypertens 2012;30:2345-51. https://doi.org/10.1097/HJH.0b013e3283591595

38 Papandreou C. Independent associations between fatty acids and sleep quality among obese patients with obstructive sleep apnoea syndrome. J Sleep Res 2013;22:569-72. https://doi.org/10.1111/jsr.12043

39 Ezzedini R, Darabi M, Ghasemi B, et al. Tissue fatty acid composition in obstructive sleep apnea and recurrent tonsillitis. Int J Pediatr Otorhinolaryngol 2013;77:1008-12. https://doi.org/10.1016/j. ijporl.2013.03.033

40 Valaiyapathi B, Calhoun DA. Role of mineralocorticoid receptors in 
obstructive sleep apnea and metabolic syndrome. Curr Hypertens Rep 2018;20:23. https://doi.org/10.1007/s11906-018-0819-5

41 Pagotto U, Vicennati V, Pasquali R. Il sistema endocannabinoide e il controllo del metabolismo energetico: fisiologia e fisiopatologia. $\mathrm{G}$ Ital Cardiol 2008;9(Suppl 1-4):74S-82S.

42 Khalyfa A, Gozal D. Connexins and atrial fibrillation in obstructive sleep apnea. Curr Sleep Med Rep 2018;4:300-11. https://doi. org/10.1007/s40675-018-0130-7

43 Park AJ, Bloom SR. Neuroendocrine control of food intake. Curr Opin Gastroenterol 2005;21:228-33. https://doi.org/10.1097/01. $\operatorname{mog} .0000153358 .05901 .3 \mathrm{f}$

44 Di Marzo V, Matias I. Endocannabinoid control of food intake and energy balance. Nat Neurosci 2005;8:585-9. https://doi.org/10.1038/nn1457

45 Paci A, Marrone O, Lenzi S, et al. Endogenous digitalislike factors in obstructive sleep apnea. Hypertens Res 2000;23:S87-91. https://doi. org/10.1291/hypres.23.Supplement_S87

46 Nonaka-Sarukawa M, Yamamoto $\mathrm{K}$, Aoki $\mathrm{H}$, et al. Increased urinary $15-\mathrm{F} 2 \mathrm{t}$-isoprostane concentrations in patients with non-ischaemic congestive heart failure: a marker of oxidative stress. Heart 2003;89:871-4. https://doi.org/10.1136/heart.89.8.871

47 Dikmenoğlu N, Ciftçi B, Ileri E, et al. Erythrocyte deformability, plasma viscosity and oxidative status in patients with severe obstructive sleep apnea syndrome. Sleep Med 2006;7:255-61. https://doi. org/10.1016/j.sleep.2005.12.005

48 Gaweł S, Wardas M, Niedworok E, et al. Malondialdehyde (MDA) as a lipid peroxidation marker. Wiad Lek 2004;57:453-5.

49 Marnett LJ. Lipid peroxidation-DNA damage by malondialdehyde. Mutat Res 1999;424:83-95. https://doi.org/10.1016/s00275107(99)00010-x

$50 \mathrm{Xu}$ H, Zheng X, Qian Y, et al. Metabolomics profiling for obstructive sleep apnea and simple snorers. Sci Rep 2016;6:30958. https://doi. org/10.1038/srep30958

51 Stanke-Labesque F, Bäck M, Lefebvre B, et al. Increased urinary leukotriene E4 excretion in obstructive sleep apnea: effects of obesity and hypoxia. J Allergy Clin Immunol 2009;124:364-70, 370.e1-2. https://doi.org/10.1016/j.jaci.2009.05.033

52 Gautier-Veyret E, Bäck M, Arnaud C, et al. Cysteinyl-leukotriene pathway as a new therapeutic target for the treatment of atherosclerosis related to obstructive sleep apnea syndrome. Pharmacol Res 2018;134:311-9. https://doi.org/10.1016/j.phrs.2018.06.014

53 Zaffanello M, Bilimler C, Hekimligi D, et al. Relationship between plasma homocysteine and obstructive sleep apneas in children: a preliminary study. EJMO 2018;2:130-4. https://doi.org/10.14744/ ejmo.2018.93685

54 Currò M, Gugliandolo A, Gangemi C, et al. Toxic effects of mildly elevated homocysteine concentrations in neuronal-like cells. Neurochem Res 2014;39:1485-95. https://doi.org/10.1007/s11064-0141338-7

55 Ganguly P, Alam SF. Role of homocysteine in the development of cardiovascular disease. Nutr J 2015;14:6. https://doi.org/10.1186/14752891-14-6

56 Kim J, Lee SK, Yoon DW, et al. Concurrent presence of obstructive sleep apnea and elevated homocysteine levels exacerbate the development of hypertension: a KoGES Six-year follow-up study. Sci Rep 2018;8:2665. https://doi.org/10.1038/s41598-018-21033-5

57 Baszczuk A, Kopczyński Z. Hyperhomocysteinemia in patients with cardiovascular disease. Postepy Hig Med Dosw 2014;68:579-89. https://doi.org/10.5604/17322693.1102340

58 Pang X, Liu J, Zhao J, et al. Homocysteine induces the expression of C-reactive protein via NMDAr-ROS-MAPK-NF- $\kappa B$ signal pathway in rat vascular smooth muscle cells. Atherosclerosis 2014;236:73-81. https://doi.org/10.1016/j.atherosclerosis.2014.06.021
59 Kaminska M, Mery VP, Lafontaine A-L, et al. Change in cognition and other non-motor symptoms with obstructive sleep apnea treatment in Parkinson disease. J Clin Sleep Med 2018;14:819-28. https:// doi.org/10.5664/jcsm.7114

60 Fletcher EC, Miller J, Schaaf JW, et al. Urinary catecholamines before and after tracheostomy in patients with obstructive sleep apnea and hypertension. Sleep 1987;10:35-44. https://doi.org/10.1093/ sleep/10.1.35

${ }_{61}$ Paik M-J, Kim D-K, Nguyen D-T, et al. Correlation of daytime sleepiness with urine metabolites in patients with obstructive sleep apnea. Sleep Breath 2014;18:517-23. https://doi.org/10.1007/s11325-013-0913-5

62 O'Driscoll DM, Horne RSC, Davey MJ, et al. Increased sympathetic activity in children with obstructive sleep apnea: cardiovascular implications. Sleep Med 2011;12:483-8. https://doi.org/10.1016/j. sleep.2010.09.015

63 Gislason T, Hedner J, Terenius L, et al. Substance P, thyrotropin-releasing hormone, and monoamine metabolites in cerebrospinal fluid in sleep apnea patients. Am Rev Respir Dis 1992;146:784-6. https:// doi.org/10.1164/ajrccm/146.3.784

64 Krishna J, Shah ZA, Merchant M, et al. Urinary protein expression patterns in children with sleep-disordered breathing: preliminary findings. Sleep Med 2006;7:221-7. https://doi.org/10.1016/j. sleep.2005.09.010

65 Shah ZA, Jortani SA, Tauman R, et al. Serum proteomic patterns associated with sleep-disordered breathing in children. Pediatr Res 2006;59:466-70. https://doi.org/10.1203/01. pdr.0000198817.35627.fc

66 Gozal D, Jortani S, Snow AB, et al. Two-dimensional differential in-gel electrophoresis proteomic approaches reveal urine candidate biomarkers in pediatric obstructive sleep apnea. Am J Respir Crit Care Med 2009;180:1253-61. https://doi.org/:10.1164/rccm.2009050765OC

67 Seetho IW, Siwy J, Albalat A, et al. Urinary proteomics in obstructive sleep apnoea and obesity. Eur J Clin Invest 2014;44:1104-15. https:// doi.org/10.1111/eci.12346

68 Lavie L. Intermittent hypoxia and obstructive sleep apnea: mechanisms, interindividual responses and clinical insights. In: Fabian Z, editor. Hypoxia. London: IntechOpen; 2019. https://doi.org/10.5772/ intechopen. 86117

69 Chen Y-C, Chen K-D, Su M-C, et al. Genome-wide gene expression array identifies novel genes related to disease severity and excessive daytime sleepiness in patients with obstructive sleep apnea. PLoS One 2017;12:e0176575. https://doi.org/10.1371/journal.pone.0176575

70 Becker L, Kheirandish-Gozal L, Peris E, et al. Contextualised urinary biomarker analysis facilitates diagnosis of paediatric obstructive sleep apnoea. Sleep Med 2014;15:541-9. https://doi.org/10.1016/j. sleep.2014.01.010

71 Arigliani M, Toraldo DM, Montevecchi F, et al. A new technological advancement of the drug-induced sleep endoscopy (DISE) procedure: The "All in One Glance" Strategy. Int J Environ Res Public Health 2020;17:4261. https://doi.org/10.3390/ijerph17124261

72 Vicini C, Colabianchi V, Marrano GG, et al. Description of the relationship between NOHL classification in drug-induced sleep endoscopy and initial AHI in patients with moderate to severe OSAS, and evaluation of the results obtained with oral appliance therapy. Acta Otorhinolaryngol Ital 2020;40:50-6. https://doi.org/10.14639/0392100X-2290

73 Salamanca F, Leone F, Bianchi A, et al. Surgical treatment of epiglottis collapse in obstructive sleep apnoea syndrome: Epiglottis stiffening operation. Acta Otorhinolaryngol Ital 2019;39:404-8. https://doi. org/10.14639/0392-100X-N0287 